\title{
Modern trends for higher education in Ukraine
}

\author{
Voloshinov S. ${ }^{*}$, Osadchyi V. ${ }^{2}$, Osadcha K. ${ }^{2}$ \\ 1 Kherson State Maritime Academy, Kherson, Ukraine \\ 2 Bogdan Khmelnitsky Melitopol State Pedagogical University, Melitopol, Ukraine
}

Received: 21.12.2018 Accepted: 27.12.2018

\begin{abstract}
The current global trends are analyzed on paper in education with order to identify the main trends of higher education in Ukraine. There are known that fast-changing information society one of its main features is uncertainty today's. There are taking into account the current trends in the educational development and information technologies in planning the work of higher education institutions will determine the development directions of higher education in Ukraine. The analysis of foreign scientific articles and studies allowed to highlight the key trends in the higher education development, which should lead to transformations in Ukraine: the impact of information and communication technology leads to further improvement of material and technical, and educational, and methodological provision of $\mathrm{HEl}$ and transformation of approaches for teaching and learning; attention to the quality of education prompts to the search for certification mechanisms and the integration of national quality assurance schemes at the international level; coordinating the universities role as institutions of culture and the commercialization needs of higher education requires coordinating local needs and priorities, taking into account standards, practices and expectations at the national and international levels; the era of the information society and increasing the role of relevant data lead to a constant analysis of the work to the law enforcement in conditions of uncertainty and rapid change in order to make managerial and strategic decisions; necessary to increase human resource capacities urges the introduction of policies to encourage and promote an interdisciplinary approach in higher education, mainly in the area of research, training and implementation of educational programs; it is important to pay attention for accelerating the implementation of educational technologies in higher education, in particular new solutions for mixed learning, a culture of innovation, study spaces redevelopment, immersed teaching methods, a collective approach for learning, open educational resources, cooperation between institutions of higher education; international practice of the educational services concept encourages the implementation and the diversification for educational programs to formal and informal education.
\end{abstract}

Key words: higher education, trends, educational technologies, information technologies.

\section{Сучасні тенденції розвитку вищої освіти в Україні}

\author{
Волошинов С. А. ${ }^{1}$, Осадчий В. В. ${ }^{2}$, Осадча К. П. ${ }^{2}$ \\ 1 Херсонська державна морська академія, Херсон, Україна \\ 2 Мелітопольський державний педагогічний університет імені Богдана Хмельницького, Мелітополь, Україна
}

\begin{abstract}
Анотація. У роботі проаналізовано сучасні глобальні тренди в освіті з метою визначення основних тенденцій розвитку вищої освіти в Україні. Відомо, що у сучасному швидкозмінному інформаційному суспільстві однією 3 основних його особливостей виступає невизначеність. Урахування сучасних тенденцій розвитку освітніх та інформаційних технологій в плануванні роботи закладів вищої освіти (ЗВО) визначатиме напрями розвитку вищої освіти України. Проведений аналіз зарубіжних наукових статей та досліджень дозволив виділити ключові тенденції розвитку вищої освіти, які мають привести до перетворень в Україні: вплив інформаційних та комунікаційних технології спричинює подальше удосконалення матеріально-технічного та навчальнометодичного забезпечення 3ВО та транссрормацію підходів до викладання та навчання; увага до якості освіти спонукає до пошуку механізмів сертифікації та інтеграції національних схем забезпечення якості на міжнародному рівні; узгодження ролі університетів як установ культури і потреб комерціалізації вищої освіти вимагає скоординувати локальні потреби та пріоритети з урахуванням стандартів, практики та очікувань на національному і міжнародному рівнях; епоха інформаційного суспільства і підвищення ролі актуальних даних спричинюють увагу до постійного аналізу роботи ЗВО в умовах невизначеності і швидкозмінності з метою прийняптя управлінських і стратегічних рішень; потреба в нарощуванні потенціалу людських ресурсів спонукає
\end{abstract}

Corresponding Author: Voloshynov Serhii Anatoliiovych. Tel. +380500107538. E-mail: s_voloshinov@ukr.net Kherson State Maritime Academy, Prospect Ushakov, 20, Kherson, Kherson region, 73009.

Відповідальний автор: Волошинов Сергій Анатоліович. Тел. +380500107538. E-mail: s_voloshinov@ukr.net Херсонська державна морська академія, проспект Ушакова, 20, Херсон, Херсонська область, Україна, 73009. 
запровадити політику для заохочення та сприяння міждисциплінарному підходу в вищій освіті як основному у сфері наукових досліджень, навчанні та реалізації освітніх програм; важливо звернути увагу на прискорення впровадження освітніх технологій у вищу освіту, зокрема нових рішень для змішаного навчання, культури інновацій, перепланування навчальних просторів, методики глибшого навчання, колективного підходу до навчання, відкритих освітніх ресурсів, співробітництва між закладами вищої освіти; міжнародна практика концепції освітніх послуг спонукає ЗВО до впровадження і урізноманітнення освітніх програм формальної та несрормальної освіти.

Ключові слова: вища освіта, тенденції, освітні технології, інформаційні технології.

\title{
Современные тенденции в развитии высшего образования в Украине
}

\author{
Волошинов С. А.' Осадчий В. В. ${ }^{2}$, Осадчая К. П. ${ }^{2}$
}

\author{
${ }_{1}^{1}$ Херсонская государственная морская академия, Херсон \\ 2 Мелитопольский государственный педагогический университет имени Богдана Хмельницкого, Мелитополь
}

\begin{abstract}
Аннотация. В работе проанализированы современные глобальные тренды в образовании с целью определения основных тенденций развития высшего образования в Украине. Известно, что в современном быстро меняющемся инфрормационном обществе одной из основных его особенностей выступает неопределенность. Учет современных тенденций развития образовательных и информационных технологий в планировании работы высших учебных заведений определяет направления развития высшего образования Украины. Проведенный анализ зарубежных научных статей и исследований позволил выделить ключевые тенденции развития высшего образования, которые должны привести к преобразованиям в Украине: влияние информационных и коммуникационных технологии требует дальнейшего совершенствования материальнотехнического и учебно-методического обеспечения ВУЗов и трансформацию подходов к преподаванию и обучению; внимание к качеству образования побуждает к поиску механизмов сертификации и интеграции национальных схем обеспечения качества на международном уровне; согласование роли университетов как учреждений культуры и потребностей коммерциализации высшего образования требует скоординировать локальные потребности и приоритеты с учетом стандартов, практики и ожиданий на национальном и международном уровнях; эпоха информационного общества и роли актуальных данных вызывают внимание к постоянному анализу работы ВУЗов в условиях неопределенности с целью принятия управленческих и стратегических решений; потребность в наращивании потенциала человеческих ресурсов побуждает к введению политики поощрения и содействия междисциплинарному подходу в высшем образовании как основному в сфере научных исследований, обучении и реализации образовательных программ; важно обратить внимание на ускорение внедрения образовательных технологий в высшем образовании, в частности новых решений для смешанного обучения, культуры инноваций, перепланировки учебных пространств, методики глубокого обучения, коллективного подхода к обучению, открытых образовательных ресурсов, сотрудничества между вузами; международная практика концепции образовательных услуг побуждает ВУЗы к внедрению и вариативности образовательных программ формального и неформального образования.
\end{abstract}

Ключевые слова: высшее образование, тенденции, образовательные технологии, инсрормационные технологии.

\section{Bcmyn}

У сучасному швидкозмінному інформаційному суспільстві однією з основних його особливостей виступає невизначеність. Вона, як зазначає Е. Тофлер, а також новизна і різноманіття спричинює глибоку апатію, яка вимикає з суспільного життя мільйони людей [1, с. 396]. Невизначеність спричинює недоліки у плануванні в системі вищої освіти, яка покликана бути рушієм суспільства. Тому аналіз сучасних освітніх та інформаційних технологій $€$ важливим для розуміння трендів, які визначатимуть напрям розвитку вищої освіти.

У зарубіжних наукових дослідженнях проблеми розвитку вищої освіти вивчалися у таких аспектах: міждисциплінарні тенденції у вищій освіті (W.J. Jacob [2]), світові тренди розвитку вищої освіти (P.G. Altbach, L. Reisberg, L. E.Rumbley [3], P. Maassen, N. Cloete [4], P. Uetela [5]), тенденції вищої освіти окремих регіонів та країн (J.N. Hawkins [6] (Азія), J. Falcon, P. Bataille [7] (Франція), R. Ravinder [8] (Еритрея), W.J. Jacob, J.N. Hawkins [9] (Китай), A.M. Kalimullin [10] (Росія)), тенденції, що прискорюють впровадження технологій у вищій освіті (L. Johnson, S.A. Becker, M. Cummins, V. Estrada, A. Freeman, C. Hall [11]), поширення нових технологій у вищій освіті (I.B. Ardashkin, A.Yu.Chmykhalo, M.A. Makienko, M.A. Khaldeeva [12]) та ін. Шляхи розвитку у вищій освіті України вивчалися Т.В. Фініковим [13], 
В. Андрущенком [14] та ін.; тенденції розвитку інформаційно-комунікаційних технологій в освіті В.В. Осадчим, К.П. Осадчою [15], М.П. Шишкіною [16], та ін.. Проте виникає потреба в аналізі сучасних глобальних освітніх трендів з метою визначення основних тенденцій розвитку вищої освіти в Україні.

\section{II Матеріал і методи дослідження}

У звіті 2009 року «Тенденції глобальної вищої освіти: відстеження академічної революції» (Trends in Global Higher Education: Tracking an Academic Revolution) П.Г. Альтбах, Л. Рейсберг, Л.Е. Румблай [6] визначають такі основні вектори розвитку вищої освіти: нові технології, турбота про якість, боротьба за суть вищої освіти, професіоналізація управління вищою освітою та лідерство. Щодо першої тенденції дослідники зазначають, що вплив інформаційних та комунікаційних технології можна побачити в обміні знаннями через електронну пошту, блоги, вікі та підкасти, в швидкому поширенні дистанційної освіти й електронних видань наукових журналів і книг, а також певною мірою в управлінні закладами вищої освіти (3ВО). Наступним етапом цього процесу є транссрормація підходу до викладання та навчання, що не означає заміни традиційних університетів або традиційних методів навчання. Разом із тим спостерігається величезна різниця у тому, наскільки різні країни можуть інтегрувати нові технології. Від швидкості усунення «цифрового розриву» у країнах, що розвиваються залежить стан розвитку вищої освіти у них.

Автори звіту вважають, що якість і надалі буде високим пріоритетом для вищої освіти, що на наступному етапі спостерігається тенденція необхідності рухатися до взаємного визнання та довіри, 3 тим щоб національні програми забезпечення якості передбачали міжнародну валідність. Незважаючи на більш ніж десятиріччя формалізації програм забезпечення якості, багато елементів якості вимірювань та моніторингу залишаються проблематичними.

Як наголошується у звіті, університети, що традиційно розглядаються як основні установи культури, що відповідають за просвітництво суспільства, все частіше зобов'язані реагувати на численні нові виклики економіки. «Комерціалізація» вищої освіти спричинила значне навантаження на її соціальну місію, що перешкоджає діяльності закладів вищої освіти в умовах зростаючих фрінансових обмежень та впливу ринку.

Тенденція прагнення до професіоналізації управління вищою освітою та лідерства обумовлена тим, що заклади вищої освіти стають все більшими та важливішими для суспільства та окремих осіб. Академічні установи та системи починають збирати дані про себе для використання в розробці та вдосконаленні політики, тому що існує зростаюча потреба у повних і точних регіональних та міжнародних даних для аналізу. Вищий навчальний заклад просто занадто великий, складний та центральний для управління без даних та професіоналізму.

В. Дж. Джейкоб, висвітлюючи тенденції у вищій освіті через призму міждисциплінарного підходу, зазначає цей підхід до дослідження та навчання $є$ важливим для того, щоб найкращим чином відповісти на динамічні потреби сьогоднішніх студентів вищої освіти [2]. Він стверджує, що нині фіксується збільшення кількості міждисциплінарних досліджень серед аспірантів у багатьох ссрерах навчання. Серед основних тенденцій науковець також виділяє збільшення й урізноманітнення курсів і ступенів та появу гібридних засобів доставки навчального матеріалу, що швидко стає світовим стандартом у вищій освіті. Масові відкриті онлайн-курси (МВОК) вносять нову динаміку в навчання, тому що до них часто зараховуються студенти з багатьох різних спеціальностей, а також студенти, що не мають ступеня. Також відмічається зростання співробітництва між університетами. Спільні програми навчання і сертифікації, організовані в різних університетах, нині розглядаються як більш реалістичні або допустимі в сучасних технологічних рамках порівняно з минулим. Конкурентні програми в майбутньому можуть реалізовуватися за моделлю мережі Universitas 21 або моделлю консорціуму Semester Online, розробленою компанією «2U» та 13 вищими навчальними закладами Австралії, Ірландії та Сполучених Штатах, які спільно пропонують курси в Інтернеті студентам університетів-учасниць.

Детально прослідкувати зміни у тенденціях розвитку вищої освіти можна за допомогою звітів NMC Horizon щодо вищої освіти. За шість років здійснення досліджень щодо найважливіших технологічних розробок, що забезпечать значний вплив на розвиток системи освіти у всьому світі, NMC (The New Media Centers) виділено тенденції, гострі проблеми і найважливіші досягнення в сфрері технологій або методик, які, ймовірно, отримають широке поширення в відповідному секторі в найближчі п'ять років. 
У звітах виділено такі ключові тенденції, що прискорюють впровадження технологій у вищу освіту: рішення для змішаного навчання, акцент на кількісному оцінюванні навчання, удосконалення культури інновацій, перепланування навчальних просторів, глибше навчання (deeper learning), колективний підхід до навчання, еволюція онлайн-навчання, переосмислення ролі викладачів, розповсюдження відкритих освітніх ресурсів, переосмислення методів роботи освітніх установ, співробітництво між закладами, студенти у ролі творців, гнучкий підхід до перетворень, повсюдний доступ до соціальних мереж, змішання формального і неформального навчання, децентралізована підтримка інформаційних технологій, повсякденне навчання (табл. 1).

Табл. 1. Ключові тенденції у вищій освіті за 2012-2017 рр. за версією NMC

\begin{tabular}{|c|c|c|c|}
\hline Рік & \multicolumn{3}{|c|}{ Ключові тенденції } \\
\hline $\begin{array}{c}2012 \\
{[17]}\end{array}$ & \multicolumn{3}{|c|}{$\begin{array}{l}\text { рішення для змішаного навчання, глибше навчання (deeper learning), колективний } \\
\text { підхід до навчання, переосмислення ролі викладачів, децентралізована підтримка } \\
\text { інформаційних технологій, повсякденне навчання }\end{array}$} \\
\hline $\begin{array}{c}2013 \\
{[17]}\end{array}$ & \multicolumn{3}{|c|}{$\begin{array}{l}\text { рішення для змішаного навчання, акцент на кількісному оцінюванні навчання, } \\
\text { еволюція онлайн-навчання, переосмислення ролі викладачів, розповсюдження } \\
\text { відкритих освітніх ресурсів, змішання фоормального і неформального навчання }\end{array}$} \\
\hline $\begin{array}{c}2014 \\
{[17]}\end{array}$ & \multicolumn{3}{|c|}{$\begin{array}{l}\text { рішення для змішаного навчання, акцент на кількісному оцінюванні навчання, } \\
\text { еволюція онлайн-навчання, студенти у ролі творців, гнучкий підхід до перетворень, } \\
\text { повсюдний доступ до соціальних мереж }\end{array}$} \\
\hline & Короткострокові & Середньострокові & Довгострокові \\
\hline $\begin{array}{c}2015 \\
{[18]}\end{array}$ & $\begin{array}{l}\text { рішення для змішаного } \\
\text { навчання, перепланування } \\
\text { навчальних просторів }\end{array}$ & $\begin{array}{l}\text { акцент на кількісному } \\
\text { оцінюванні навчання, } \\
\text { розповсюдження відкритих } \\
\text { освітніх ресурсів }\end{array}$ & $\begin{array}{l}\text { удосконалення культури } \\
\text { інновацій, співробітництво } \\
\text { між закладами }\end{array}$ \\
\hline $\begin{array}{c}2016 \\
{[11]}\end{array}$ & $\begin{array}{l}\text { акцент на кількісному } \\
\text { оцінюванні навчання, } \\
\text { рішення для змішаного } \\
\text { навчання }\end{array}$ & $\begin{array}{l}\text { перепланування } \\
\text { навчальних просторів, } \\
\text { глибше навчання (deeper } \\
\text { learning) }\end{array}$ & $\begin{array}{l}\text { удосконалення культури } \\
\text { інновацій, переосмислення } \\
\text { методів роботи освітніх } \\
\text { установ }\end{array}$ \\
\hline $\begin{array}{c}2017 \\
{[19]}\end{array}$ & $\begin{array}{l}\text { рішення для змішаного } \\
\text { навчання, колективний } \\
\text { підхід до навчання }\end{array}$ & $\begin{array}{l}\text { акцент на кількісному } \\
\text { оцінюванні навчання, } \\
\text { перепланування } \\
\text { навчальних просторів }\end{array}$ & $\begin{array}{l}\text { удосконалення культури } \\
\text { інновацій, глибше } \\
\text { навчання (deeper learning) }\end{array}$ \\
\hline
\end{tabular}

\section{III Результати}

Ґрунтуючись на даних у звітах NMC Horizon щодо вищої освіти слід зазначити, що наведені вище ключові тенденції безпосередньо впливають на політику, керівництво і практику закладів вищої освіти. Опишемо докладніше основні тенденції, що були виділені у звіті 2017 року: рішення для змішаного навчання, колективний підхід до навчання акцент на кількісному оцінюванні навчання, перепланування навчальних просторів удосконалення культури інновацій, глибше навчання (deeper learning).

Рішення для змішаного навчання. Технологія змішаного навчання у світі та Україні зокрема розвивається вже кілька десятиліть. Те, що в останні роки сприйняття онлайн-навчання стало більш 
позитивним, число платформ для цифрового навчання і способів їх використання в освітніх цілях зросло і продовжує зростати, дозволяє відносити змішане навчання до сучасних тенденцій у вищій освіті.

Низька вартість змішаного навчання, його гнучкість і доступність, а також можливість застосування в навчальному процесі складних технологій - все це робить його вкрай привабливим. Поточний інтерес до цієї тенденції еволюціонував до розуміння того, як цифрові моделі викладання впливають на студентів.

Багато досліджень свідчать про розвиток творчого мислення у студентів, підвищенні їх здатності до самостійного навчання, а також здатності адаптувати навчальний процес з метою задоволення своїх індивідуальних потреб [19, с. 18].

Колективний підхід до навчання [19, с. 20]. Цей підхід також не є новим, але завдяки появі і розвитку нових інформаційно-комунікаційних технологій вні розглядається як сучасна тенденція у вищій освіті. Адже поширення комунікаційних Інтернет-сервісів, хмарних технологій, програм для спільного навчання та інших цифрових засобів забезпечують постійний зв'язок через Інтернет, дозволяючи студентам і викладачам у будь-який час працювати над спільними проектами, а платформи для адаптивного навчання дозволяють обмінюватися даними про досягнення студентів в масштабах всього навчального закладу. Це у свою чергу допомагає удосконалити навчальний процес у ЗВО та сприяє розвитку вищої освіти.

Акцент на кількісному оцінюванні навчання. Ця тенденція обумовлена тим, що вимоги сучасного ринку праці змінюються під впливом соціальних і економічних чинників. У зв'язку з цим коледжам і університетам необхідно переосмислювати саме визначення успішності з різних предметів, а також способи оцінювання і демонстрації знань з різних дисциплін, навичок творчої роботи і співпраці. Широке поширення програмного забезпечення для інтелектуального аналізу даних і досягнення в онлайн-освіті, мобільному навчанні і системах управління навчанням ведуть до появи навчальних середовищ, які використовують програмні засоби для аналітики і візуалізації з метою представлення даних про навчання в багатовимірному і портативному вигляді. У курсах онлайн- і змішаного навчання зібрані дані можуть показати, наскільки ті чи інші дії студентів сприяють їх прогресу і досягненню конкретних навчальних цілей [19, с. 14].

Перепланування навчальних просторів. У зв'язку із прагненням зробити навчальні аудиторії більш придатними до інтерактивного навчання, дистанційного й віртуального навчання університети застосовують сучасне технічне забезпечення (мультимедійні дошки, великі дисплеї, інтерактивні панелі та інші цифрові елементи), що, в свою чергу, вимагає перепланування навчальних приміщень. Крім цього, університети досліджують технології доповненої реальності, що дозволяють привнести в навчальний приміщення голографічний тривимірний контент для різних симуляцій. У міру того як вища освіта переходить від традиційних лекцій до більш практичних форм навчання, навчальні аудиторії все більше нагадують реальні робочі i соціальні середовища, що полегшує природну взаємодію i забезпечує міждисциплінарний підхід до вирішення проблем [19, с. 16].

Удосконалення культури інновацій. На відміну від науковців П.Г. Альтбаха, Л. Рейсберга та Л.Е. Румблая, які зазначали про негативні наслідки комерціоналізації вищої освіти, у звіті NMC Horizon наголошується на важливості ролі ЗВО як «двигуна інновацій». При цьому велике значення має відмова від існуючого у вищій освіті статус-кво і визнання невдачі важливою частиною процесу навчання. Інтеграція підприємництва в сферу вищої освіти - це додаткове підтвердження того, що кожна велика ідея повинна з чогось починатися, а у студентів і викладачів може бути все необхідне для справжнього прориву. Для того, щоб йти в ногу з часом, ЗВО необхідно критично переглянути свій навчальний план і змінити методи оцінки, адже бар'єри, що перешкоджають розвитку нових ідей, повинні бути усунені [19, c. 10].

Глибше навчання (deeper learning). Ця довгострокова тенденція базується на розумінні поняття «глибше навчання» як навчання, метою якого є досягнення кожним студентом прогресу в освоєнні як академічних стандартів, так і розвитку можливостей і здатностей, що необхідні для успіху в коледжі, кар'єрі, суспільстві та житті [20]. Для того, щоб навчання стимулювало критичне мислення, навички вирішення проблем, співробітництва та самостійності, студент повинен бачити прямий зв'язок між навчальною програмою і реальним світом і розуміти, як отримані знання і навички будуть реалізовані на 
практиці. Навчання на основі проектів, навчання на основі проблем, навчання на основі досліджень та інші подібні підходи сприяють отриманню більш практичного навчального досвіду. Створення студентських спільнот для навчання, розробка викладачами нових навчальних програм, співпраця студентів і викладачів - ці досягнення в сфрері глибокого навчання підвищують його популярність у вищій освіті [19, с. 12].

\section{IV Обговорення}

Виділені тенденції надають можливості для розвитку і прискорюють процес модернізації вищої освіти та узгодження її змісту з потребами сучасного суспільства. Адже еволюція технологій впливає на суспільство і воно вимагає від освіти адекватних стратегій підготовки молодого покоління.

Глобальні тенденції безпосередньо і опосередковано впливають на освітню політику в Україні. Нині міжнародна концепція освітніх послуг призвела в Україні до збільшення кількості навчальних закладів і установ (провайдерів), що у свою чергу спричинило урізноманітнення очікувань та потреб бажаючих отримати освіту. Розвиток освітньої системи в країні вимагає додаткового прибутку та нових каналів для його отримання. Все це (збільшення провайдерів освітніх послуг, урізноманітнення освітніх потреб та дефріцит фінансування) викликає побоювання щодо забезпечення якості освіти та її дискредитації. Ця тенденція буде продовжуватися, адже багато людей сьогодні бажають отримати професійній навички швидко і не дорого, що дозволяють зробити провайдери неформальної та інформальної освіти. Але сформувати всебічно розвинену людину, носія культурних та інтелектуальних традицій нації можуть лише заклади вищої освіти з багаторічною історією і культурою навчання і виховання підростаючого покоління.

Вища освіта має підготувати молодь до здійснення професійної діяльності в умовах невизначеності і швидкозмінності. Це завдання вимагає від політиків, керівників 3ВО та викладачів переглянути структуру традиційних програм підготовки, а також трансформувати педагогіку минулого, традиційні підходи до викладання на нові, що більш відповідають умовам сучасного інфрормаційного суспільства.

\section{V Висновки}

Аналіз зарубіжних наукових статей та досліджень дозволяє виділити такі ключові тенденції розвитку вищої освіти, які мають привести до перетворень в Україні:

1) вплив інформаційних та комунікаційних технології має підштовхнути не лише до аудиту і модернізації наявного апаратно-програмного забезпечення й мережної інфраструктури 3ВО, а й до подальшого удосконалення навчально-методичного забезпечення та трансформації підходів до викладання та навчання;

2) увага до якості освіти і прагнення до інтеграції у світових освітній простір мають спонукати 3ВО докласти необхідні спільні зусилля для пошуку механізмів сертифікації та інтеграції національних схем забезпечення якості на міжнародному рівні;

3) ЗВО потрібно збалансувати роль університетів як установ культури і вплив соціальних та економічних зрушень, що вимагають комерціалізації вищої освіти, а також узгодити локальні потреби та пріоритети з урахуванням стандартів, практики та очікувань на національному і міжнародному рівні;

4) епоха інформаційного суспільства і підвищення ролі достовірних і актуальних даних спричинюють увагу до постійного аналізу роботи ЗВО в умовах невизначеності і швидкозмінності 3 метою прийняття управлінських і стратегічних рішень, тому збір і аналіз даних про діяльність ЗВО має стати пріоритетом у розвитку вищої освіти;

5) зважаючи на потребу в нарощуванні потенціалу людських ресурсів потрібно запровадити політику для заохочення та сприяння міждисциплінарному підходу в вищій освіті як основному у сфері наукових досліджень, навчання та реалізації освітніх програм;

6) важливо звернути увагу на ключові тенденції, що прискорюють впровадження освітніх технологій у вищу освіту, зокрема на нові рішення для змішаного навчання, удосконалення культури інновацій, потреби у переплануванні навчальних просторів, методику глибшого навчання, оновлення 
колективного підходу до навчання, розповсюдження відкритих освітніх ресурсів, співробітництво між закладами вищої освіти;

7) застосування в Україні міжнародної практики концепції освітніх послуг спричинює зростання конкуренції у цій сфрері, зокрема у частині перепідготовки професійних кадрів, що має спонукати ЗВО до впровадження і урізноманітнення освітніх програм формальної та неформальної освіти 3 метою утримання і закріплення позицій ЗВО як осередків якісних освітніх послуг.

Врахування цих тенденцій у плануванні роботи закладів вищої освіти сприятиме стабільному їх розвитку та прогресу вищої освіти України, інтеграції у світовий освітній простір та подоланню наслідків нерівномірного розподілу людського капіталу, що дозволить країні повною мірою скористатися новими можливостями сучасних освітніх та інформаційних технологій.

\section{Бібліографічні посилання}

[1] Тоффрлер Э. Шок будущего. М. : ООО «Издательство АСТ», 2002. 557 с.

[2] Jacob W. Interdisciplinary trends in higher education / Palgrave Communications. 2015. Vol. 1. URL: https://www.nature.com/articles/palcomms20151. doi: 10.1057/palcomms.2015.1 (дата звернення 19.12.2018).

[3] Altbach P. G., Reisberg L., Rumbley L. E. Trends in Global Higher Education: Tracking an Academic Revolution. A Report Prepared for the UNESCO 2009 World Conference on Higher Education. URL: http://www.cep.edu.rs/public/Altbach,_Reisberg,_Rumbley_Tracking_an_Academic_Revolution,_UNESCO_2009.pdf (дата звернення 19.12.2018).

[4] Maassen P., Cloete N. Global Reform Trends in Higher Education / Transformation in Higher Education. 2006. Vol. 10, P. 733. URL: https://doi.org/10.1007/1-4020-4006-7_2 (дата звернення 10.01.2019).

[5] Uetela P. Higher Education and Development: Global Trends / Higher Education and Development in Africa. 2017. URL: https://doi.org/10.1007/978-3-319-31141-8_2 (дата звернення 10.01.2019).

[6] Hawkins J. N. Trends and Developments in Higher Education in the Asia-Pacific Region / Oxford Research Encyclopedia of Education. 2018. URL: https://doi.org/10.1093/acrefore/9780190264093.013.60 (дата звернення 10.01.2019).

[7] Falcon J., Bataille P. Equalization or Reproduction? Long-Term Trends in the Intergenerational Transmission of Advantages in Higher Education in France / European Sociological Review. 2018. Vol. 34. Is. 4. P. 335-347. URL: https://doi.org/10.1093/esrljcy015 (дата звернення 10.01.2019).

[8] Ravinder R. Higher Education Trends in Eritrea. International Higher Education. 2015. № 51. P. 12-18. URL: https://doi.org/10.6017/ihe.2008.51.8009 (дата звернення 10.01.2019).

[9] Jacob W. J., Hawkins J.N. Trends in Chinese Higher Education: Opportunities and Challenges / Trends in Chinese Education. 2016. 1stEdition. P. 20-22, https://doi.org/10.3726/978-3-653-05441-5/19. (дата звернення 10.01.2019).

[10] Kalimullin, Aydar M. (2017). Organizational, content, and technological updating of educational process in modern Russian higher schools in the conditions of science and education integration / New Trends and Issues Proceedings on Humanities and Social Sciences. Vol. 2. № 11. P. 70-77. URL: https://doi.org/10.18844/prosoc.v2i11.1905 (дата звернення 10.01.2019).

[11] Johnson L., Adams Becker S., Cummins M., Estrada V., Freeman A., Hall C. NMC Horizon Report: 2016 Higher Education Edition. Austin : The New Media Consortium. 2016. 56 p. URL: http://cdn.nmc.org/media/2016-nmc-horizon-report-he-EN.pdf (дата звернення 19.12.2018).

[12] Ardashkin I.B., Chmykhalo A.Yu., Makienko M.A., Khaldeeva M.A. Smart-Technologies In Higher Engineering Education: Modern Application Trends / The European Proceedings of Social \& Behavioural Sciences EpSBS. 2018. Vol. L. P. 57-64. URL: https://doi.org/10.15405/epsbs.2018.12.8 (дата звернення 10.01.2019).

[13] Фініков Т. В. Сучасна вища освіта: світові тенденції і Україна. К. : Таксон, 2002. 176 с.

[14] Андрущенко В. Вища освіта у пост-Болонському просторі: спроба прогностичного аналізу / Філософія освіти. 2005. № 2. C. 6-12.

[15] Осадчий В.В., Осадча К. П. Сучасні реалії і тенденції розвитку інфоормаційно-комунікаційних технологій в освіті / Інформаційні технологї̈ і засоби навчання. 2015. Т. 48. № 4. С. 47-57. URL: https://journal.iitta.gov.ua/index.php/itt/article/viewFile/1252/951 (дата звернення 19.12.2018).

[16] Шишкіна М. П. Тенденції розвитку та використання інформаційних технологій у контексті формування освітнього середовища / Інформаційні технології і засоби навчання. 2006. T. 1. № 1. URL: https://journal.iitta.gov.ua/index.php/ittl/article/view/287/273 (дата звернення 19.12.2018).

[17] NMC Horizon Report. 2017 Higher Education Edition (Russian). URL: https://www.nmc.org/publication/nmc-horizon-report2017-higher-education-edition-russian (дата звернення 19.12.2018).

[18] Johnson L., Adams Becker S., Estrada V., Freeman A. NMC Horizon Report: 2015 Higher Education Edition. Austin : The New Media Consortium. 2015. 56 p. URL: https://files.eric.ed.gov/fulltext/ED559357.pdf (дата звернення 19.12.2018).

[19] Adams Becker S., Cummins M., Davis A., Freeman A., Hall Giesinger C., Ananthanarayanan V. NMC Horizon Report: 2017 Higher Education Edition. Austin, Texas: The New Media Consortium. 2017. 60 p. URL: https://www.sconul.ac.uk/sites/defaultfiles/documents/2017-nmc-horizon-report-he-EN.pdf (дата звернення 19.12.2018).

[20] Vision 2020. Excellence with Equity. URL: https://www.jefferson.kyschools.us/sites/default/files/Vision-2020-Brochure.pdf (дата звернення 19.12.2018). 


\section{References}

[1] Toffler, A. (2002). Shok budushcheho, Moscow, Russia. [in Russian]

[2] Jacob, W. (2015), "Interdisciplinary trends in higher education", Palgrave Communications, Vol.1, available at: https://www.nature.com/articles/palcomms20151 (accessed December 19, 2018). doi: 10.1057/palcomms.2015.1. [in English]

[3] Altbach, P.G., Reisberg, L., Rumbley, L. E. (2009), Trends in Global Higher Education: Tracking an Academic Revolution. A Report Prepared for the UNESCO 2009 World Conference on Higher Education, available at: http://www.cep.edu.rs/public/Altbach,_Reisberg,_Rumbley_Tracking_an__ Academic_Revolution,_UNESCO_2009.pdf (accessed December 19, 2018). [in English]

[4] Maassen, P., Cloete, N. (2006). Global Reform Trends in Higher Education, Transformation in Higher Education, Vol. 10, pp. 7-33. , available at: https://doi.org/10.1007/1-4020-4006-7_2(accessed January 10, 2019) [in English]

[5] Uetela, P. (2017). Higher Education and Development: Global Trends, Higher Education and Development in Africa, available at: https://doi.org/10.1007/978-3-319-31141-8_2 (accessed January 10, 2019) [in English]

[6] Hawkins, J.N. (2018). Trends and Developments in Higher Education in the Asia-Pacific Region, Oxford Research Encyclopedia of Education, available at: https://doi.org/10.1093/acrefore/9780190264093.013.60 (accessed January 10, 2019) [in English]

[7] Falcon, J., Bataille, P. (2018). Equalization or Reproduction? Long-Term Trends in the Intergenerational Transmission of Advantages in Higher Education in France, European Sociological Review, Vol. 34 (4), pp. 335-347. URL: https://doi.org/10.1093/esr/jcy015 (accessed January 10, 2019) [in English]

[8] Ravinder, R. (2015). Higher Education Trends in Eritrea, International Higher Education, Iss. 51, pp. 12-18. , available at: https://doi.org/10.6017/ihe.2008.51.8009 (accessed January 10, 2019) [in English]

[9] Jacob W. J., Hawkins J.N. (2016). Trends in Chinese Higher Education: Opportunities and Challenges, Trends in Chinese Education, 1stEdition, pp. 20-22, available at: https://doi.org/10.3726/978-3-653-05441-5/19 (accessed January 10, 2019) [in English]

[10] Kalimullin, A.M. (2017). Organizational, content, and technological updating of educational process in modern Russian higher schools in the conditions of science and education integration, New Trends and Issues Proceedings on Humanities and Social Sciences, Iss. 2 (1), pp. 70-77, available at: https://doi.org/10.18844/prosoc.v2i11.1905 (accessed January 10, 2019) [in English]

[11] Johnson, L., Adams Becker, S., Cummins, M., Estrada, V., Freeman, A., Hall, C. (2016), NMC Horizon Report: 2016 Higher Education Edition, Austin : The New Media Consortium, 56 p., available at: http://cdn.nmc.org/media/2016-nmc-horizonreport-he-EN.pdf accessed December 19, 2018). [in English]

[12] Ardashkin, I.B., Chmykhalo, A.Yu., Makienko, M.A., Khaldeeva, M.A. (2018). Smart-Technologies In Higher Engineering Education: Modern Application Trends, International Conference on Research Paradigms Transformation in Social Sciences, Vol. L, pp. 57-64. , available at: https://doi.org/10.15405/epsbs.2018.12.8 (accessed January 10, 2019) [in English]

[13] Finikov, T.V. (2002). Suchasna vyshcha osvita: svitovi tendentsii i Ukraina, Kyiv, Ukraine. [in Ukrainian]

[14] Andrushchenko, V. (2005). Vyshcha osvita u post-Bolonskomu prostori: sproba prohnostychnoho analizu, Filosofiia osvity, Iss. 2, pp. 6-12. [in Ukrainian]

[15] Osadchyi, V.V., Osadcha, K.P. (2015). Suchasni realii i tendentsii rozvytku informatsiino-komunikatsiinykh tekhnolohii v osviti, Informatsiini tekhnolohii i zasoby navchannia, Iss. 48 (4), pp. 47-57, available at: https://journal.iitta.gov.ua/index.php/itt/article/viewFile/1252/951 (accessed December 19, 2018) [in Ukrainian]

[16] Shyshkina, M.P. (2006). Tendentsii rozvytku ta vykorystannia informatsiinykh tekhnolohii u konteksti formuvannia osvitnoho seredovyshcha, Informatsiini tekhnolohii $i$ zasoby navchannia, Iss. 1 (1), available at: https://journal.iitta.gov.ua/index.php/itt//article/view/287/273 (accessed December 19, 2018). [in Ukrainian]

[17] (2017). NMC Horizon Report. 2017 Higher Education Edition (Russian), available at: https://www.nmc.org/publication/nmchorizon-report-2017-higher-education-edition-russian (accessed December 19, 2018) [in English]

[18] Johnson, L., Adams Becker, S., Estrada, V., and Freeman, A. (2015), NMC Horizon Report: 2015 Higher Education Edition, Austin : The New Media Consortium, 56 p., available at: https://files.eric.ed.gov/fulltext/ED559357.pdf (accessed December 19, 2018) [in English]

[19] Adams Becker, S., Cummins, M., Davis, A., Freeman, A., Hall Giesinger, C., Ananthanarayanan, V. (2017). NMC Horizon Report: 2017 Higher Education Edition, Austin : The New Media Consortium, 60 p., available at: https://www.sconul.ac.uk/sites/default/files/documents/2017-nmc-horizon-report-he-EN.pdf (accessed December 19, 2018). [in English]

[20] Vision 2020. Excellence with Equity, available at: https://www.jefferson.kyschools.us/ sites/default/files/Vision-2020Brochure.pdf (accessed December 19, 2018) [in English] 


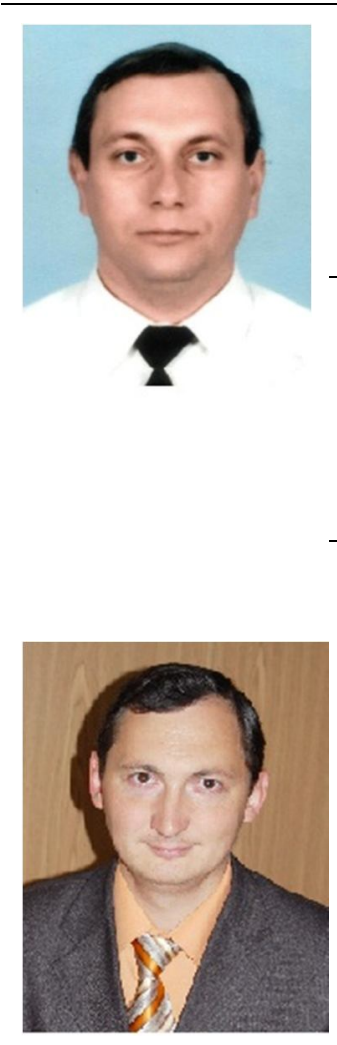

Волошинов Сергій Анатоліович,

кандидат педагогічних наук, доцент, доцент кафедри інноваційних технологій та технічних засобів судноводіння,

Херсонська державна морська академія,

проспект Ушакова, 20, Херсон, Херсонська область, Україна, 73009.

Тел. +380500107538. E-mail: s_voloshinov@ukr.net

Voloshynov Serhii Anatoliiovych,

Candidate of Pedagogical Sciences, Associate Professor, Associate Professor of the Department of

Innovative Technologies and Technical Means of Navigation, Associate Professor, Kherson State Maritime Academy,

Prospect Ushakov, 20, Kherson, Kherson region, 73009.

Tel.+380500107538. E-mail: s_voloshinov@ukr.net

ORCID: https://orcid.org/0000-0001-9127-9999

\section{Осадчий Вячеслав Володимирович,}

д.пед.н., профресор, профресор кафедри інфооратики і кібернетики,

Мелітопольський державний педагогічний університет імені Богдана Хмельницького,

вул. Гетьманська, 20, м. Мелітополь Запорізька обл., Україна, 72312.

Тел. (0619) 44-04-64. E-mail: osadchyi@mdpu.org.ua

\section{Osadchyi Viacheslav Volodymyrovych,}

Doctor of Pedagogical Science, Professor, Professor of the Department of Informatics and Cybernetics,

Bogdan Khmelnitsky Melitopol State Pedagogical University,

Str. Getmanska, 20, Melitopol, Zaporozhye region, Ukraine, 72312.

Tel. (0619) 44-04-64. E-mail: osadchyi@mdpu.org.ua

ORCID: https://orcid.org/0000-0001-5659-4774

Researcher ID: http://www.researcherid.com/rid//-8586-2016

Scopus ID: 57190217440

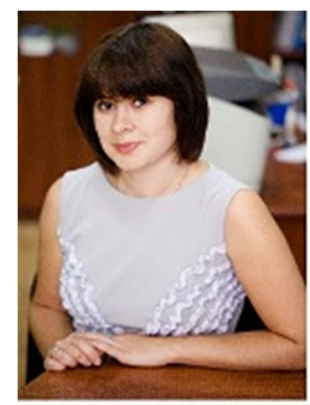

\section{Осадча Катерина Петрівна,}

к.пед.н., доцент, доцент кафедри інсорматики і кібернетики,

Мелітопольський державний педагогічний університет імені Богдана Хмельницького,

вул. Гетьманська, 20, м. Мелітополь Запорізька обл., Україна, 72312.

Тел. (0619) 44-04-64. E-mail: okp@mdpu.org.ua

\section{Osadcha Kateryna Petrivna,}

Candidate of Pedagogical Sciences, Associate Professor, Associate Professor of the Department of Informatics and Cybernetics, Bogdan Khmelnitsky Melitopol State Pedagogical University,

Str. Getmanska, 20, Melitopol, Zaporozhye region, Ukraine, 72312.

Tel. (0619) 44-04-64. E-mail: okp@mdpu.org.ua

ORCID: https://orcid.org/0000-0003-0653-6423

Researcher ID: http://www.researcherid.com/rid/L-5268-2016

Scopus ID: 57198803878

\section{Citation (APA):}

Voloshinov, S., Osadchyi, V., Osadcha, K. (2018). Modern trends for higher education in Ukraine. Engineering and Educational Technologies, 6 (4), 38-46. doi: https://doi.org/10.30929/2307-9770.2018.06.04.04

\section{Цитування (ДСТУ 8302:2015):}

Волошинов С. А., Осадчий В. В., Осадча К. П. Сучасні тенденції розвитку вищої освіти в Україні / Інженерні та освітні технологіï. 2018. Т. 6. № 4. С. 38-46. doi: https://doi.org/10.30929/2307-9770.2018.06.04.04

Обсяг статmі: $\quad$ сторінок- 9 ; умовних друк. аркушів - $1,034$. 